\title{
Optimization of the Refractive Index of Antireflection Coatings on Monocrystalline Silicon Solar Cells for Photovoltaic Application
}

\author{
Awa Dieye $^{1 \#(1)}$, El Hadji Abdoulaye Niasse ${ }^{2}$, Oumar Absatou Niasse $^{3}$, Alassane Diaw $^{3}$, \\ Modou Pilor ${ }^{4}$, Nacire Mbengue ${ }^{5}$, Moulaye Diagne ${ }^{6}$, Bassirou $\mathrm{Ba}^{7}$ \\ 1,2,3,4,5,6,7Physical Department, University Cheikh Anta Diop of Dakar, 5005 Dakar, Senegal.
}

\#corresponding author

Type of Work: Peer Reviewed.

DOI: 10.21013/jas.v16.n4.p2

DOI URL: https://dx.doi.org/10.21013/jas.v16.n4.p2

How to cite this paper:

Dieye, A. et al. (2021). Optimization of the Refractive Index of Antireflection Coatings on

Monocrystalline Silicon Solar Cells for Photovoltaic Application. IRA-International Journal of Applied Sciences (ISSN 2455-4499), 16(4), 68-73. DOl: https://dx.doi.org/10.21013/jas.v16.n4.p2

(C) IRA Academico Research.

(c) B EY-Nc This work is licensed under a Creative Commons Attribution-NonCommercial 4.0 International License subject to a proper citation to the publication source of the work.

Disclaimer: The scholarly papers as reviewed and published by IRA Academico Research are the views and opinions of their respective authors and are not the views or opinions of IRA Academico Research. IRA Academico Research disclaims any harm or loss caused due to the published content to any party.

IRA Academico Research is an institutional publisher member of Publishers International Linking Association Inc. (PILA-CrossRef), USA. IRA Academico Research is an institutional signatory to the Budapest Open Access Initiative. Hungary advocating the open access of scientific and scholarly knowledge. IRA Academico Research is also a registered content provider under Open Access Initiative Protocol for Metadata Harvesting (OAl-PMH).

This paper is peer-reviewed under IRA Academico Research's Peer Review Program.

Awa Dieye (iD/0000-0003-0986-0632 


\begin{abstract}
In this work, the following materials have been chosen as anti-reflection layer, namely hafnium (HfO2), magnesium fluoride (MgF2), silicon oxynitrides ( $\mathrm{SiOxNy}$ ), silicon oxides ( $\mathrm{SiOx}$ ), silicon nitride (Si3N4) and hydrogenated silicon nitride $(\mathrm{SiNx}: \mathrm{H})$. The calculations were made on the basis of values of layer thicknesses and refractive indices that allow the phase and amplitude conditions to be respected and amplitude conditions. Numerical simulations have shown that low reflectivities at the surface of the surface of the plane cell coated with a simple layer, can be obtained. For example, for simple coatings materials based on Si3N4 and $\mathrm{HfO} 2$, we obtain a value of reflectivity around 3 and $2 \%$ respectively. The structures with multilayer coatings such as $\mathrm{MgF} 2 / \mathrm{SiNx}: \mathrm{H} / \mathrm{Si}$, give a reflectivity of around $1 \%$. Thus, the refraction index of the coating is an important parameter that plays a major parameter that plays a major role in the optical properties of materials. The closer the refractive index is close to the index of the substrate or the layer above the substrate, the higher the reflectivity.
\end{abstract}

Keywords: Anti-reflective coating, single layer, multi-layer, reflection, refractive index

\title{
Introduction
}

Energy production is a central issue in our societies, with repercussions at all levels (economic, geopolitical, environmental, social...). Energy is indeed consumed, in its various forms, by all sectors of activity. Solar energy is one of the sustainable, abundant and clean solutions. It is obtained by converting the sun's rays into electricity through silicon, on which there is a very high reflection of the incident ray, thus a high loss. In order to reduce the reflectivity, the use of an anti-reflection layer (CAR) is anti-reflection layer (CAR) was imposed.

\section{Influence of the Refractive Index of the Anti-reflective Coating}

The evolution of the reflection coefficient of a silicon solar cell has been examined in this section. The substrate is coated with a single layer of anti-reflection material. The materials considered are $\mathrm{MgF}_{2}, \mathrm{Si}_{3} \mathrm{~N}_{4}, \mathrm{SiN}_{\mathrm{x}}$ : $\mathrm{H}, \mathrm{SiO}_{\mathrm{x}} \mathrm{N}_{\mathrm{y}}$, $\mathrm{SiO}_{2}, \mathrm{HfO}_{2}$, whose index and thickness values used for the calculation are listed table below at the reference length of $700 \mathrm{~nm}[1,2,3,4]$.

Table .1 Materials used as anti-reflection layers with their refractive indices and optimum thicknesses for a reference wavelength $\lambda_{0}=700 \mathrm{~nm}$.

\begin{tabular}{|c|c|c|}
\hline \multicolumn{3}{|c|}{$\lambda_{0}=700 \mathrm{~nm}$} \\
\hline Materials & $\begin{array}{c}\text { Refractive } \\
\text { indexes }\end{array}$ & $\begin{array}{c}\text { Thickness } \\
(\mathrm{nm})\end{array}$ \\
\hline $\mathrm{MgF}_{2}$ & 1,38 & 127,17 \\
\hline $\mathrm{SiO}_{\mathrm{x}}$ & 1,50 & 116,67 \\
\hline $\mathrm{SiO}_{\mathrm{x}} \mathrm{N}_{\mathrm{y}}$ & 1,80 & 97,22 \\
\hline $\mathrm{Si}_{3} \mathrm{~N}_{4}$ & 2,03 & 86,11 \\
\hline $\mathrm{HfO}_{2}$ & 2,10 & 83,37 \\
\hline $\mathrm{SiN}_{\mathrm{x}}: \mathrm{H}$ & 2,30 & 58,33 \\
\hline $\begin{array}{c}\mathrm{Si} \\
\text { (substrat) }\end{array}$ & 3,78 & 46,20 \\
\hline
\end{tabular}

Fig. 8 shows a variation of the reflectivity from $400 \mathrm{~nm}$ to $1000 \mathrm{~nm}$ for the various coatings of the solar cell, the minimal value is observed for the reference wavelength ref $(\lambda 0)=700 \mathrm{~nm}$. It is observed, the structures $\mathrm{Si} 3 \mathrm{~N} 4 / \mathrm{Si}$, $\mathrm{SiOxNy} / \mathrm{Si}$ and $\mathrm{HfO} 2 / \mathrm{Si}$, present a null reflectivity at the reference wavelength, knowing that for the monocrystalline silicon the reflectivity turns around $33 \%$ at this same reference wavelength.

This shows the importance of the coatings which makes the reflectivity pass to a value almost null thus generating a rather important transmission within the cells with an anti-reflection layer[5,6,7,8]. 


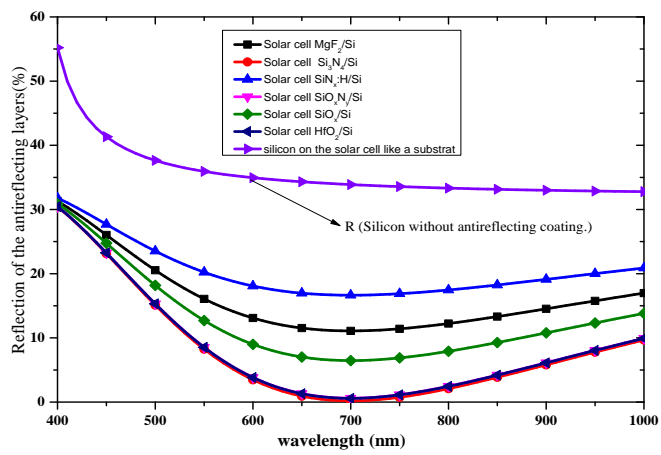

Fig.1: Reflection of antireflective single-wave structures on silicon (reference wavelength $700 \mathrm{~nm}$ )

Beyond the reference wavelength, the reflectivity varies between 1 and $33 \%$ for all the different types of antireflective coatings.

The decrease in reflectivity for the three coatings mentioned above is due to the fact that these materials have refractive indices very close to the optimal index $\mathrm{n}=1.96\left(\mathrm{nSiO}_{\mathrm{x}} \mathrm{N}_{\mathrm{y}}=1.80, \mathrm{nSi}_{3} \mathrm{~N}_{4}=2.03, \mathrm{nHfO}_{2}=2.10\right)$ and which correspond to the condition of obtaining destructive interference between the rays reflected by the coating. The transmission of the photon flow within the cell is thus improved.

However, the other coatings whose refractive indices present a deviation from the optimal index, the $\mathrm{N}$ conditions of destructive interference are not achieved. The optical path is much weaker, which leads to a decrease in reflectivity within the cells with anti-reflective coatings. The influence of the refractive indices shows the importance of the choice of the material as antireflection layer.

\section{Study on Double Layer Anti-reflective Coatings}

\section{Research of the Best Configuration for Double Layers}

The different anti-reflective materials used in this work will allow us to see their influence on different structures, namely coatings with decreasing refractive indices from the substrate $(n=3.78)$ to the ambient medium, the air $(\mathrm{n}=1)$.

The study in simulation is made by considering the materials of Table. 1 coupled two by two in order to seek the best configuration of double anti-reflection layer $[9,10,11]$.

\section{Reflection Coefficient of an Anti-reflection Double Layer $\left(\mathrm{SiO}_{\mathrm{x}} / \mathrm{HfO}_{2}\right)$ on Silicon}

The variation of the reflection coefficient of the double anti-reflection layer (DARC) with $\mathrm{SiO}_{\mathrm{x}}$ and $\mathrm{HfO}_{2}$ materials) is calculated in the wavelength range $400 \mathrm{~nm}-1000 \mathrm{~nm}$ and plotted in Fig. 2.

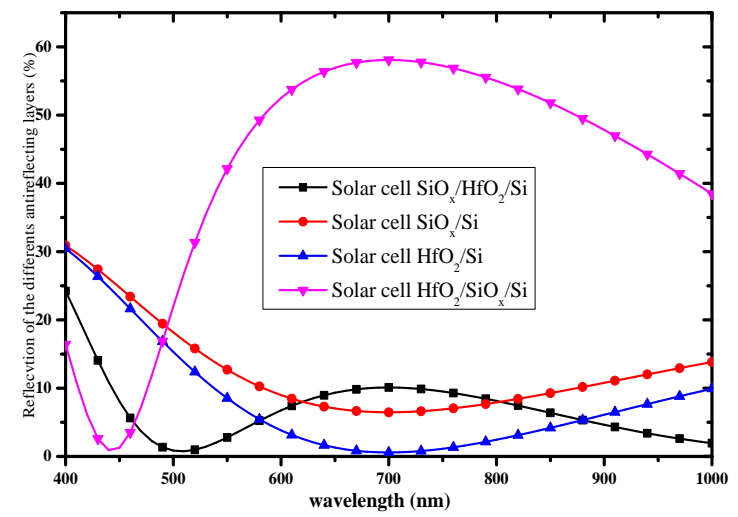

Fig. 2: Reflectivity of DARC SiOx/HfO $/ 2 / \mathrm{Si}$ and $\mathrm{HfO}_{2} / \mathrm{SiOx} / \mathrm{Si}$ structures. 
The study was made on two configurations namely the $\mathrm{SiOx} / \mathrm{HfO}_{2} / \mathrm{Si}$ and $\mathrm{HfO} 2 / \mathrm{SiOx} / \mathrm{Si}$ structures. The $\mathrm{SiOx} / \mathrm{HfO}_{2} / \mathrm{Si}$ structure, (whose material indices are in the order of 1.50, 2.10 and 3.78) shows a reflectivity of $10 \%$ at the reference wavelength. For the $\mathrm{HfO}_{2} / \mathrm{SiOx} / \mathrm{Si}$ structure (with material indices in the order of $2.10,1.50$ and 3.78), where the anti-reflection layers have been inverted, the reflection coefficient reaches $60 \%$. This reflects the importance of the order in which the anti-reflective materials are deposited on the substrate; it is, therefore, necessary to deposit the layers in decreasing indices from the substrate to the top layer.

The fig. 3 also shows that single-layer coatings perform better at the reference wavelength. However, the two-layer coatings show zero reflectivities at $450 \mathrm{~nm}$ for the $\mathrm{HfO}_{2} / \mathrm{SiOx} / \mathrm{Si}$ structure and $500 \mathrm{~nm}$ for the $\mathrm{SiOx} / \mathrm{HfO}_{2} /$ structure closer to the reference wavelength. This shift of the minimum reflectivity towards short wavelengths could be due to the fact that the juxtaposition of the two layers modifies the optical path of the waves in the materials. This leads to a change in phase that corresponds to destructive interference at another wavelength.

\section{Reflection Coefficient of a SiOxNy / $\mathrm{Si}_{3} \mathrm{~N}_{4}: \mathrm{H}$ Antireflection Double Layer on Silicon}

The curves of fig. 3represent the variation of the reflection coefficient of a DCAR ( $\left.\mathrm{SiOxNy} / \mathrm{Si}_{3} \mathrm{~N}_{4}: \mathrm{H}\right)$ according to the wavelength.

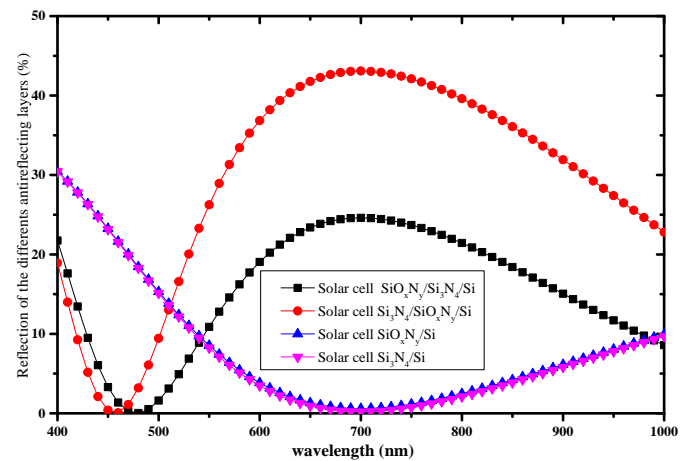

Fig.3: Reflectivity of DARC SiOxNy/Si ${ }_{3} \mathrm{~N}_{4} / \mathrm{Si}$ and $\mathrm{Si}_{3} \mathrm{~N}_{4} / \mathrm{SiOxNy} / \mathrm{Si}$ structures.

The value of the reflection coefficient for both structures is obtained at wavelengths between 450 and $500 \mathrm{~nm}$, while it becomes maximum at the reference wavelength. The same behavior observed in the previous section is noted here also when reversing the order of deposition of the AR layers.

\section{Reflection Coefficient of an Antireflection Double Layer $\left(\mathrm{MgF}_{2} / \mathrm{SiNx}: \mathrm{H}\right)$ on Silicon}

The same observations and remarks of the two previous sections are noted in the case of the $\mathrm{MgF}_{2} / \mathrm{SiNx}: \mathrm{H} / \mathrm{Si}$ and $\mathrm{SiNx}: \mathrm{H} / \mathrm{MgF}_{2} / \mathrm{Si}$ structures (see Fig. 4 and 5).

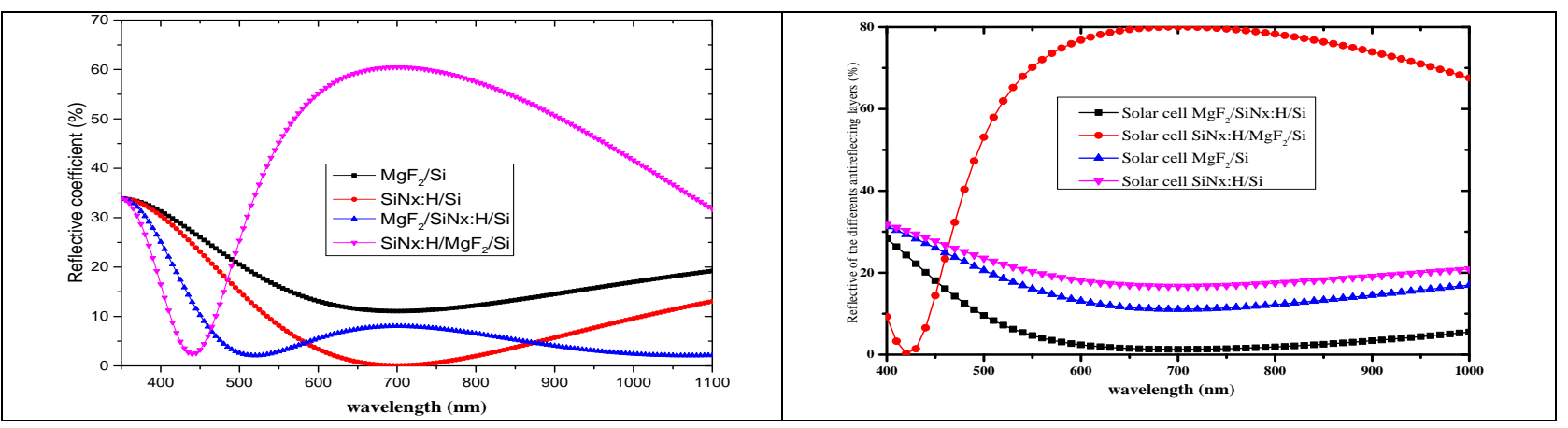


IRA-International Journal of Applied Sciences

Fig. 4:Reflectivity of structures $\mathrm{MgF}_{2} / \mathrm{SiNx}: \mathrm{H} / \mathrm{Si}$ et $\mathrm{SiNx}: \mathrm{H} / \mathrm{MgF}_{2} / \mathrm{Si}$.

Index $n=2$ pour le $\mathrm{SiNx}: \mathrm{H}$
Fig.5:Reflectivity of structures $\mathrm{MgF}_{2} / \mathrm{SiNx}: \mathrm{H} / \mathrm{Si}$ et $\mathrm{SiNx}: \mathrm{H} / \mathrm{MgF}_{2} / \mathrm{Si}$.

Index $n=3$ pour le $\operatorname{SiNx}: H$

The observation of these two graphs, in relation to the increasing or decreasing order of the refractive indices and the change of refractive index of the SiNx:H material, $(n=2$ then $n=3)$, largely shows the influence of the refractive indices and the order in which the materials are deposited. The reflectivity is minimal in the structure with decreasing refractive indices from the substrate to the top layer $\left(\mathrm{MgF}_{2} / \mathrm{SiNx}: \mathrm{H} / \mathrm{Si}\right)$.

In the case of the SiNx:H/MgF$/ 2$ Si structure, and referring to Fig. 4 and 5, the reflectivity increases from 60 to $80 \%$ in the visible spectrum from $650 \mathrm{~nm}$ to $750 \mathrm{~nm}$ by taking the values of refractive index $\mathrm{n}=2$, then $\mathrm{n}=3$, respectively. This shows that the greater the difference between the indices of the anti-reflective layers, the higher the reflection for that where the top layer at a higher index. The opposite is observed for the $\mathrm{MgF}_{2} / \mathrm{SiNx}: \mathrm{H} / \mathrm{Si}$ structure for which the change of the index of $\mathrm{SiNx}: \mathrm{H}$ from $\mathrm{n}=2$ to $\mathrm{n}=3$, gives a variation of the reflectivity of $8 \%$ to $2 \%$ at the reference wavelength. This is compounded by almost no reflectivity in a longer wavelength range of 650 to $750 \mathrm{~nm}$.

\section{Variation of the Refractive index of One of the Antireflection Layers}

Fig. 6shows the theoretical calculations developed for a material of variable refractive index and forming an intermediate layer between the substrate $(\mathrm{Si})$ and the magnesium fluoride $\left(\mathrm{MgF}_{2}\right)$ of index $\mathrm{n}=1.38[12,13,14,15]$.

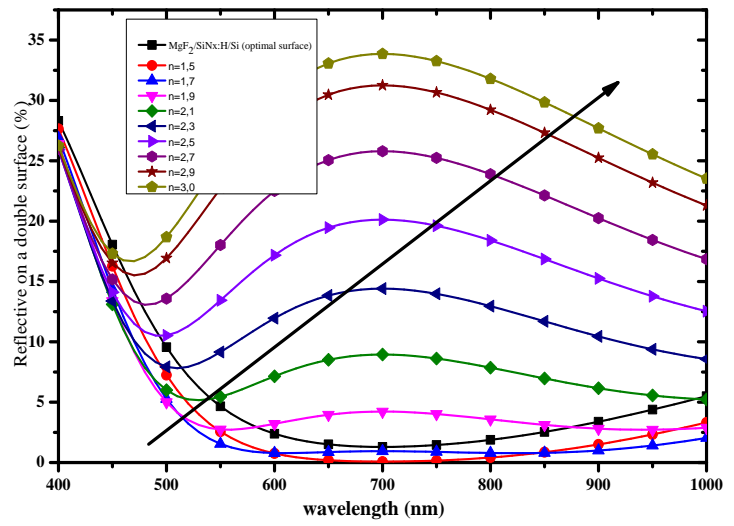

Fig. 6: Variation of the refractive index of an antireflective layer as a function of wavelength.

For the simulations, the material index is taken between the values of the refractive index of $\operatorname{MgF} 2(\mathrm{n}=1.38)$ and $\mathrm{n}$ $=3$. The decrease of the reflection coefficient as a function of wavelength is observed when the material index increases. At the same time, it is observed that the wavelength range for which the reflectivity is zero, becomes wider as the index increases.

\section{Conclusion}

This article was devoted to the simulation of anti-reflection layers involving, the best anti-reflection materials and the optimization of their performance. Anti-reflection layers play an important role in reducing optical losses in silicon solar cells which is a highly reflective material (60\% loss of incident light flux). The variety of materials that can be used as anti-reflection layers provides several solutions. Among these different materials, magnesium fluoride $\left(\mathrm{MgF}_{2}\right)$, silicon nitride $\left(\mathrm{Si}_{3} \mathrm{~N}_{4}\right)$ and silicon oxide $\left(\mathrm{SiO}_{2}\right)$, have shown interesting properties by reducing to less than $35 \%$ the reflectivity of silicon. The closer the index of the layer is to the optimal index nair $\times$ nsilicon, the more the reflectivity becomes practically zero in the spectrum centered around the reference length that has been chosen in this work equal to $700 \mathrm{~nm}$. Because of their respective properties, the combination of these materials in double layer, can be exploited to reduce both optical losses and losses related to recombination of minority carriers on the front side by passivation. Theoretical analysis has shown that a combination of two materials with appreciable index differences reduces the reflectivity of silicon over a wide spectral band as in the case of the double layer coating $\mathrm{MgF}_{2} / \mathrm{SiNx}: \mathrm{H} / \mathrm{Si}$ whose indices are respectively 1.3767 and 2.3000. On the other hand, if the values of 
the indices of the materials of the double layer are very close, the reflectivity becomes important in the part of the spectrum centered around the reference wavelength.

The option of making anti-reflection coatings to reduce photon losses at the surface of silicon, obeys certain conditions. It requires the development of calculation models, allowing to take into account the components of the different media (air / antireflection / silicon). The matrix approach is more general and allows to treat several layers, including interfaces. However, it is necessary to find a good compromise between the thickness of the AR layer to be deposited on the substrate and the adequate material to obtain the minimum of reflection in the active area of the silicon.

\section{References}

[1]. R. W. Birkmire and E. Eser, "Polycrystalline thin-film solar cells: Present status and future potential", Annual Review of Materials Science, 27 (1997), 1 - 24.

[2]. H.J. Hovel, R. K. Willardson, A. C. Beer, Semiconductors and semimetals, Vol 11, Solar cells, New York, Academic Press, 1975.

[3]. F. Pelanchon, P. Mialhe et J. P. Charles, "Optimisation du rendement d'unephotopile», Revue Physique Appliquée, 23, (1988), 1139 - 1145.

[4]. G. E. Jellison Jr., R. F. Wood, “Antireflection coatings for planar silicon solar cells”, Solar Cells 18 (1986) 93.

[5]. J. Zhao, M. A. Green, "Optimized antireflection coatings for high-efficiency silicon solar cells", IEEE Trans. on Electronic Dev. 38, (8) (1991), 1925 - 1934.

[6]. P. A. Iles, "Antireflection coatings for solar cells", J. Vac. Sci. Technol. 14 (1977) 1100.

[7]. P. A. Young, W. G. Thege, "Two-layer laser antireflection coatings“, J. Phys. D: Appl. Phys. 4 (1971) 64.

[8]. J. Thomas Cox, Georg Hass, "Antireflection coatings for optical and infrared optical materials in Physics of Thin Films Collec., Vol. 2, Academic Press, New York, 1964.

[9]. S. Khorasani, B. Rashidian, "Modified transfer matrix method for conducting interfaces", J. Opt. A: Pure and Appl. Opt. 4 (2002) $251-256$.

[10]. P. Kosoboutskyy, M. Karkulovska, A Morgulis, "The principle of multilayer plane parallel structure antireflection", Optica Applicata, Vol. XL, No. 4 (2010), 759- 765.

[11]. D. Bouhafs, A. Moussi, A. Chikouche, J.M. Ruiz "Design and simulation of antireflection coating systems for optoelectronic devices: Application to silicon solar cells”, Solar Energy Materials and Solar Cells, 52 (1998) 79 93.

[12]. N. Mbengue, M. Diagne, M. Niane, A. Dieye, O. A. Niasse, B. Ba, "Optimization of Double Anti-Reflective Coating SiOx/SiNx on the Solar Cells with Silicon Conventional”, IJETT) - Vol. 20 N$^{\circ} 2$, (2015), $101-104$.

[13]. P. Rouard, «Etudes des propriétés optiques des lames métalliques très minces », Ann. Phys., 117 (1937) 291 384

[14]. F. Abelès, « Recherches sur la propagation des ondes électromagnétiques sinusoïdales dans les milieux stratifiés. Application aux couches minces », Ann. De Physique 5 (1950), 596 - 639.

[15]. S. A. Dyakov, V. A. Tolmachev, E. V. Astrova, S. G. Tikhodeev, V. Yu. Timoshenko, T. S. Perova, "Numerical methods for calculation of optical properties of layered structures", Proc. of SPIE Vol. 7521, (2010), 75210G/10. 